\title{
When Politics Trumps Health: Undocumented Latino Immigrants and US Health Care
}

\begin{abstract}
Alexander N. Ortega PhD
Donald Trump, an American reality-television celebrity and business mogul, is at this writing a front-running Republican in the bid for the US presidency. His opening salvo as a candidate included charges that Mexican immigrants, particularly the unauthorized, are rapists and criminals and that they bring their problems with them to the USA. He also tied immigration from Latin America to a potential increase in terrorism in the country. Trump may not be taken seriously by some, but his conjectures have revved up antiimmigration sentiment, with other Republican presidential candidates renewing proposals for building a wall along the US-Mexican border and advocating stricter immigration laws and enforcement. The underlying sentiment is that undocumented Mexican immigrants represent a clear "negative" to US society, a theory also applied to those from many other countries.
\end{abstract}

A common assumption of today's proponents of strict immigration reform is that unauthorized (or "undocumented") immigrants come into the country and use public resources, especially health care, to which they are not entitled or have not earned. However, for sound health policymaking, it is important to untangle and demystify this line of reasoning to get to the facts, and also to understand the potential consequences of excluding undocumented immigrants from access to services such as health care.

Let's first address the fundamental question of whether undocumented immigrants are a drain on our nation's resources. It is estimated that there are 11.4 million undocumented immigrants in the United States, $81 \%$ from Latin America. While their proportion has been declining over the past few years, Mexicans make up approximately $58 \%$ of the total, while immigrants from other Latin American countries account for the remaining $23 \%$. At the same time, immigration from Asia, the Middle East and Africa is rising. Six states account for over $60 \%$ of unauthorized immigrants (California, Texas, Florida, New York, New Jersey and Illinois). Undocumented laborers make up a bit over $5 \%$ of the US workforce. Collectively, undocumented immigrants contribute approximately $\$ 12$ billion per year in state, local and federal taxes, and this is expected to increase by $\$ 2.2$ billion under the Obama Administration's proposed comprehensive immigration reform. Moreover, they pay an estimated $\$ 13$ billion per year into Social Security, from which they receive no benefit.[1]

It is well known that in the USA, not everyone has equal access to health care. In fact, at $40 \%$, undocumented Latinos have among the lowest levels of insurance coverage and thus are more likely to have to pay for health services out of pocket. They also use very little primary or secondary health care.[2] When they use primary health care, they typically seek services at busy, poorly funded community clinics or in more costly hospital emergency departments. These facilities can be of low quality and without sufficient resources to provide language-concordant care. Ironically, while some of those $60 \%$ without insurance may receive indigent care, the services provided them in safety-net facilities are often subsidized by federal and state provisions - to which their taxes contribute.
The Affordable Care Act (ACA) became law in 2010, intended to improve health insurance coverage for the approximately 30 million uninsured in the USA at that time, either through the Medicaid expansion program or one of the health insurance Marketplace exchanges. Recent data show that the ACA is working: some 17 million more people have been insured since 2013, and 9 in 10 US citizens and residents now have insurance.[3] However, undocumented immigrants are excluded from the ACA. Latinos who are legally authorized but have been in the country less than five years are also excluded from participation in the Medicaid expansion program.

This exclusion of undocumented immigrants from the ACA raises a number of population health/clinical, economic and moral issues. And all have consequences. On the population health front, because the undocumented have low insurance coverage rates and are blocked from the ACA, they are less likely to receive preventive care, more likely to delay seeking necessary care, and have worse chronic disease morbidity and mortality as a result.

On the economic side, the undocumented are also, on average, young, healthy, and use relatively little health care. Including them in the ACA, particularly in the Marketplace exchanges, would be economically beneficial, offsetting higher costs of treating older and chronically ill patients. This would also provide them greater access to preventive services and reduce delays in seeking needed health care, resulting in long-term cost savings to health plans and taxpayers, not to mention overall better community health.

Finally, there is the moral issue: a fundamental premise of any sustainable society is that health care is a human right. Surely in the USA, the richest country in the world, this right must be guaranteed for everyone, entire segments of the population not excluded a priori.

As the ACA continues to expand and researchers and policymakers begin to understand its effects on population health, ironing out the snags for more effective implementation, it will be in the country's best interests to reconsider including the undocumented in the legislation. Right now, they are simply living in hopes of staying healthy without health care, while their tax dollars help pay for an Affordable Care Act whose benefits they do not receive. - 1

1. Bora K. Immigration Reform: If legalized, tax paid by undocumented workers would increase by $2.2 \mathrm{~B}$, study says. Int Business Times [Internet]. $2015 \mathrm{Apr}$ 16 [cited 2015 Jul 20]; Politics: [about 3 p.]. Available from: http://www.ibtimes .com/immigration-reform-if-legalized-tax-paid-undocumented-workers-would -increase-22b-1884286

2. Ortega AN, Fang H, Perez VH, Rizzo JA, Carter-Pokras O, Wallace SP, et al. Health care access, use of services, and experiences among undocumented Mexicans and other Latinos. Arch Intern Med. 2007 Nov 26;167(21):2354-60.

3. Fox M. Nine in 10 Americans have insurance, survey finds. NBC News [Internet]. 2015 Aug 12 [cited 2015 Sep]; [about 4 screens]. Available from: http:// www.nbcnews.com/storyline/obamacare-deadline/more-americans-covered -health-insurance-survey-finds-n408436

Submitted: September 3, 2015

Approved for publication: September 13, 2015

Disclosures: None

Correspondence: aortega@ucla.edu 